\title{
ANDIL PEMURIDAN KONTEKSTUAL YESUS KEPADA PETRUS YAKOBUS DAN YOHANES TERHADAP KETERBUKAAN KONSELING MAHASISWA PADA MASA KINI
}

\author{
Oleh : \\ ${ }^{* 1}$ T. Haryono dan ${ }^{* 2}$ Daniel Fajar Panuntun. \\ ${ }^{* 1}$ Dosen Tetap STT Gamaliel \\ ${ }^{*}$ Alumnni STT Gamaliel \\ Email : ${ }^{* 1}$ tharyono@stt-gamaliel.ac.id,${ }^{* 2}$ danielfajar@stt-gamaliel.ac.id
}

\begin{abstract}
ABSTRAK - Perkembangan dunia secara global menuntut adanya standar kompetensi tinggi. Mahasiswa dituntut untuk survive dalam persaingan global sehingga berakibat stress pada mahasiswa. Dampak lainnya adalah pola penutupan diri pada mahasiswa sehinga mereka tidak dapat dikonseling. Penelitian ini berfokus untuk mengetahui andil pemuridan kontekstual (Kelompok Tumbuh Bersama Kontekstual / KTBK) yang didasari dari pemuridan Yesus kepada Petrus, Yakobus, dan Yohanes dalam kaitannya dengan keterbukaan mahasiswa pada masa kini. Pendekatan yang dilakukan adalah dengan pendekatan kualitatif yang melibatkan studi pustaka dan studi lapangan terbatas. Analisis dilakukan dengan analisis interaktif. Penelitian ini menghasilkan bahwa model KTBK memiliki andil dalam keterbukaan konseling pada mahasiswa pada masa kini.
\end{abstract}

Kata kunci : Pemuridan, Kontekstual, Yesus, Konseling, KTBK.

\begin{abstract}
The Develop of the world globally demanded a high standar competence. The collegers must be survived in global competition so that caused stress into them. The other effect were a self closure of them so they cannot been counseling. This Research was focused to knew the contribution of the contextual discipleship (CBG) that based on of Jesus discipliship into Peter, James and John in relation with the openess of the collegers nowadays. The approach of this research was used qualitative method with a book study and field limited study. The analysis was done withe the interactive analysis. This research is produce that $C B G$ model has contribution into the openess of the collegers counseling nowadays.
\end{abstract}

Keyword: Dicipleship, Contextual, Jesus, Counseling, CBG.

\section{Latar Belakang Masalah}

Perkembangan dunia secara global menuntut adanya standar kompetensi tinggi dalam menghadapi persaingan. Hal ini menyebabkan semakin tajamnya persaingan antar-negara dan antarorganisasi dalam merebut pasar serta usaha menghasilkan kinerja dan kualitas produk 
yang prima. ${ }^{1}$ Persaingan global ini telah terjadi di seluruh akibat adanya kemudahan teknologi dan iptek.

Beberapa Penelitian menunjukan dampak persaingan terbuka ini kaitannya dengan sumber daya manusia yang ada di Indonesia, diantaranya: Pengembangan kompetensi sumber daya manusia (SDM) untuk mencapai Carreer Ready Profesional $^{2}$, Tantangan kompetisi global dan dampaknya terhadap tuntutan pengem-bangan kualitas $\mathrm{SDM},{ }^{3}$ kapasitas UMKM menghadapi pasar global ${ }^{4}$, dan lain sebagainya.

Berdasarkan penelitian tersebut, menuntut adanya proses perubahan dan pengembangan menuju ke arah kemajuan bangsasangat erat hubungannya dengan proses pendidikan. Variabel pendidikan ini memiliki kedudukan yang sangat strategis dalam berperan meningkatkan kualitas sumberdaya manusia. ${ }^{5}$ Salah satu peserta pendidikan adalah pada jenjang mahasiswa

${ }^{1}$ Ika Ruhana, "Pengembangan Kualitas Sumber Daya Manusia VS Daya Saing Global”, Jurnal Profit, Vol 6, No 1, 2012. 51

2 Ahmad Azmy, "Pengembangan Kompetensi Sumber Daya Manusia Untuk Mencapai Career Ready Professional Di Universitas Tanri Abeng”, Jurnal Binus Bussines Review, Vol 6, No 2, 2015. 220.

3 Umar Chadiq, "Tantangan Kompetisi Global Dan Dampaknyaterhadap Tuntutan Pengembangan Kualitas Sumber Daya Manusia”, Akses: Jurnal Ekonomi dan Bisnis, Vol 1, No 2, 2006. 137.

${ }^{4}$ Tamjuddin, “ Kapasistas UMKM Menghadapi Pasar Global”, Semonas Fekon : optimsme ekonomi Indonesia 2013, antara peluang dan tantangan. 2013. 687.

${ }^{5}$ Umar Chadiq, "Tantangan Kompetisi Global Dan Dampaknyaterhadap Tuntutan Pengembangan Kualitas Sumber Daya Manusia”, Akses: Jurnal Ekonomi dan Bisnis, Vol 1, No 2, 2006. 137. yang harus dipersiapkan dalam menghadapi kompetisi ini.

Mahasiswa dituntut untuk survive dalam persaingan global sehingga berakibat stress pada mahasiswa. Beberapa penelitian konseling untuk menanggulangi stress pada mahasiswa diantaranya: Studi Eksplorasi tentang Pentingnya Layanan Bimbingan Konseling Bagi Mahasiswa di UMISIDA6, Self Disclosure dan Tingkat Stres pada Mahasiswa yang sedang Mengerjakan Skripsi ${ }^{7}$, Pengaruh Diskusi Kelompok Untuk Menurunkan Stres Pada Mahasiswa Yang Sedang Skripsi ${ }^{8}$, dan sebagainya. Berdasarkan hal tersebut penelitian konseling pada mahasiswa cukup banyak dan beraneka ragam, akan tetapi belum ada fokus penelitian agar mahasiswa dapat terbuka untuk konseling di tengah pengaruh kompetisi global.

Model Pemuridan Kontesktual atau KTBK (Kelompok Tumbuh Bersama Kontekstual) adalah sekelompok orang yang telah didiami Roh Kristus, terdiri dari 3-6 orang yang berkomitmen untuk bertumbuh ke arah dewasaan penuh dalam Kristus. ${ }^{9}$ KTBK merupakan salah satu

\footnotetext{
${ }^{6}$ Dwi Nastiti dan Nur Habibah, "Studi Eksplorasi tentang Pentingnya Layanan Bimbingan Konseling Bagi Mahasiswa di UMISIDA", Psikologia : Jurnal Psikologi, Vol 1, No 1, 2016. 52.

${ }^{7}$ Witrin Gamayanti et al, "Self Disclosure dan Tingkat Stres pada Mahasiswa yang sedang Mengerjakan Skripsi”, Psymphatic: Jurnal Ilmiah Psikologi. Vol 5, No 1, 2018. 115.

8 Faridah Ainur Rohmah, "Pengaruh Diskusi Kelompok Untuk Menurunkan Stres Pada Mahasiswa Yang Sedang Skripsi", Humanitas: Indonesian Psychological Journal, Vol 3 , No 1, 2006. 50

${ }^{9}$ T. Haryono dan Yuliati, Pemuridan Kontekstual : Contextual Bible Group. (Surakarta, Yayasan Gamaliel, 2018), 60.
} 
bentuk kelompok pertumbuhan rohani bagi mahasiswa. KTBK diharapkan membuat mahasiswa dapat terbuka melalui kelompok-kelompok pemahaman Alkitab, sehingga mahasiswa -tidak hanya karena masalah stress akan tetapi juga karena masalah pertumbuhan rohani, dapat terbuka untuk konseling sehingga setiap permasalahan dapat diselesaikan di dalam Kristus.

Permasalahan mahasiswa pada masa kini berkaitan dengan stress yang berdampak pada ketidakterbuakaan yang diakibatkan oleh stress dan tuntutan persaingan global yang harus dapat ditemukan solusi pemecahannya. Permasalahan tersebut dapat dikaitkan dengan KTBK. Titik temu permasalahan mahasiswa tersebut dengan andil dari model Pemuridan Kontektual harus dapat dibuatkan suatu model acuannya.

\section{Rumusan Masalah}

Berdasarkan latar belakang tersebut dapat ditarik suatu rumusan masalah penelitian yaitu: bagaimana andil model Pemuridan Kontekstual (KTBK) bagi sikap keterbukaan konseling mahasiswa masa kini?

\section{Tujuan dan Manfaat Penelitian}

Tujuan dari penelitian ini adalah untuk mengetahui andil model Pemuridan Kontesktual (KTBK) bagi sikap keterbukaan konseling mahasiswa masa kini. Manfaat yang diperoleh dari hasil penelitian ini adalah: pertama mengembangkan andil KTBK secara maksimal bagi pertumbuhan jasmani dan rohani setiap mahasiswa. Kedua dapat mengatasi permasalahan konseling antara konselor dan konseli akibat adanya sikap tidak saling terbuka. Ketiga menolong mahasiswa bertumbuh sampai dewasa serupa Yesus.

\section{Metode Penelitian}

Metodologi penelitian pada penelitian ini adalah menggunakan pendekatan kualitatif. $^{10}$ Analisis yang digunakan dalam penelitian ini adalah dengan menggunakan metode interaktif yaitu pengumpulan data, penyajian data, reduksi data dan penarikan kesimpulan. ${ }^{11}$ Penelitian ini juga melibatkan penelitian lapangan dengan wawancara ${ }^{12}$ yang dibatasi pada mahasiswa Persekutuan Mahasiswa Kristen Surakarta (PMKS).

\section{Pemuridan Kontekstual}

\section{Pemuridan Yesus dengan Petrus \\ Yakobus, Yohanes.}

Pemuridan menjadi salah satu cara yang dipakai Allah untuk mencetak generasi atau para pemimpin yang berkualitas. $^{13}$ Pemuridan Tuhan Yesus memiliki delapan langkah yaitu pemilihan, persekutuan, pengabdian, pemberian diri, peragaan, pendelegasian, pengawasan, dan

\footnotetext{
${ }^{10}$ Stevri Indra Lumintang dan Danik Astuti Lumintang, Theologia penelitian dan Penelitian Theologis science-ascience serta metodologinya, (Jakarta: Geneva Insani Indonesia, 2016), 99.

${ }^{11}$ M. B. Miles, \& Huberman, A. M. Qualitative Data Analysis: A Sourcebook of New Methods. (California. SAGE publications Inc, 1984), 23.

${ }^{12}$ Sugiyono, Metode Penelitian dan Pengembangan (Research and Development), (Bandung : Alfabeta, 2015),477-478.

${ }^{13}$ T. Haryono dan Yuliati, Pemuridan Kontekstual : Contextual Bible Group. (Surakarta, Yayasan Gamaliel, 2018), 60.
} 
multiplikasi. ${ }^{14}$ Yesus mengadakan pemuridan dengan melatih para murid. Yesus perlahan-lahan membawa para Murid-Nya melalui suatu proses yang membekali mereka dengan kualitaskualitas yang membuat mereka terpercaya menjadi pembawa kabar kesukaan. ${ }^{15}$ Fase yang terakhir adalah perubahan yang paling dramatis yang dialami oleh para murid. Yesus akan pergi dan mereka akan mulai berhubungan dengan-Nya melalui Roh Kudus dan melalui gereja-Nya. ${ }^{16}$

Pemuridan Yesus adalah melalui 12 murid-Nya, namun juga ada tiga murid yang sering disebut, yaitu Petrus, Yakobus, dan Yohanes. Pemuridan kepada Petrus, Yakobus dan Yohanes di ekposisi berdasarkan kitab Markus. Kitab Markus merupakan kitab dengan fokus bahwa Yesus adalah hamba. Melalui Khotbah, mengajar, dan menyembuhkan, Dia melayani kebutuhan orang lain bahkan sampai mati, setelah bangkit, Ia mengutus murid-murid-Nya untuk melanjutkan pekerjaan-Nya dalam kuasa-Nya Para hamba mengikuti langkah Sang Hamba yang sempurna ini. ${ }^{17}$

Kualifikasi Pemuridan Yesus didasari dari kepemimpinan Yesus. Yesus Hamba Agung memberikan penghormatan bagi mereka yang sungguh-sungguh dalam pekerjaan di dunia ini. Mereka adalah yang rajin dan mengasihi sesama yang Tuhan Yesus panggil. Tuhan memanggil dalam

\footnotetext{
${ }^{14}$ Robert Coleman, Rencana Agung Penginjilan. (Bandung: Kalam Hidup, 1964)

${ }^{15}$ A.B. Bruce. The Training of the tweleve, (Gran Rapids: Kregel Publication, 1984)

16 Bill Hull, Jesus Christ, Disciplemarker, (Surabaya: Literatur perkantas, 2015)

${ }^{17}$ Bruce Wilkinson dan Kenneth Boa,Talk Thru bible, (Malang: Gandum Mas, 2017)392
}

pekerjaannya dan memberkati mereka meskipun berkat itu dengan kata "ikutlah Aku" (Mark 16-20) ${ }^{18}$. Murid yang pertama dipanggil adalah Petrus, Yakobus, dan Yohanes. Berdasarkan hal tersebut sejak awal Tuhan Yesus sudah memberikan berkat dan perhatian khusus untuk muridnya.

Kualifikasi murid yaitu terkhusus Petrus, Yakobus dan Yohanes. Dalam kitab Markus 1:16-20, latar belakang dan kekhasan pekerjaan tidak diekspos oleh penulis. Penulis menekankan tentang kekhasan panggilan Tuhan Yesus kepada Petrus, Yakobus dan Yohanes. Keunikan dari kualifikasi murid adalah ketika Petrus, Yakobus, dan Yohanes secara langsung merespon panggilan Yesus untuk, "Ikutlah Aku'. Merekapun juga nelayan yang memiliki perahu dan bekerja secara wajar juga kemungkinan memiliki ekonomi yang baik namun tetap secara fisik mengikuti panggilan Yesus. $^{19}$ Berdasarkan hal tersebut murid-murid pertama memiliki kesediaan hati untuk bertumbuh di dalam Yesus dan menang atas himpitan kekhawatiran ekonomi. Petrus, Yakobus, dan Yohanes memberikan diri sebagai seorang murid untuk bertumbuh ke Arah Kristus.

Proses Pemuridan Yesus yang dilakukan oleh Yesus mendorong, terkhusus Petrus, Yakobus, dan Yohanes, untuk dapat terbuka. Proses pertama, Yesus mengajak secara khusus kepada

\footnotetext{
${ }^{18}$ Matthew Henry, Commentary on The Whole Bible Volume V (Matthew to John), ( Grand Rapid, MI : Christian Classics Ethereal Library, 2000), 661

${ }^{19}$ John Barton dan John Muddiman, The Oxford Bible Commentary, (United States, Oxford University Press, 2001), 889
} 
Petrus, Yakobus, Yohanes untuk melihat Yesus sebagai seorang Hamba yang penuh Kuasa. Dalam Markus 5:37, Tuhan mengajak mereka menyembuhkan anak Yairus. Pada Markus 5:38 Yesus menunjukkan ketegasannya dan hanya mengajak Ayah, Ibu, Petrus, Yakobus, Yohanes. Melalui kata Talitakum Tuhan Yesus menyembuhkan anak Yairus. ${ }^{20}$

Proses Kedua, Yesus juga mengajak Petrus, Yakobus, dan Yohanes ketika waktu dimuliakan di atas gunung (Markus 9:2-13). Transfigurasi Tuhan Yesus di saksikan oleh tiga murid tersebut. Murid tersebut yang nantinya akan menerima kesaksian tersebut dan memang hal tersebut harus dirahasiakan. Karena nantinya Yakobus adalah rasul yang mati pertama kali dan Yohanes adalah saksi mata terakhir akan penglihatan tersebut. ${ }^{21}$ Tuhan Yesus secara pribadi terbuka dan memberikan sesuatu yang khusus bagi Petrus, Yakobus, Yohanes mengenai kemuliaan-Nya. Kejadian ini hanya dikhususkan untuk Petrus, Yakobus, Yohanes.

Proses Ketiga, Yesus mengajak untuk para Murid berdoa di taman Getsemani (Markus 14 : 32-42). Pada bagian ini Yesus mengajak para muridNya untuk berdoa. Yesus merasakan ketakutan menjelang kematiannya. Petrus Yakobus dan Yohanes diajak untuk

\footnotetext{
${ }^{20}$ Robert Jamieson, et al, Commentary Critical and Explanatory on the Whole Bible, (Grand Rapid, MI : Christian Classics Ethereal Library,2009) 2215

${ }^{21}$ Matthew Henry, Commentary on The Whole Bible Volume V (Matthew to John), ( Grand Rapid, MI : Christian Classics Ethereal Library, 2000), 732
}

menemaninya. Yesus merasakan kesakitan yang sangat dan mengharapkan ketiga murid untuk mendukungnya namun mereka tidak sanggup berjaga-jaga sejam saja. ${ }^{22}$ Yesus mengajak Petrus, Yakobus, dan Yohanes berproses memahami ketakutan yang dirasakan, meskipun hasilnya mengecewakan namun proses ini menjadi bagian dari pemuridan Yesus kepada Petrus, Yakobus dan Yohanes. Peristiwa mukjizat, kemuliaan, dan ketakutan Yesus diberikan secara terbuka kepada tiga murid ini.

Proses pemuridan Yesus memiliki dampak terhadap Petrus, Yakobus, dan Yohanes. Dampak yang diekspos dari bagian ini adalah dampak keterbukan dari tiga murid ini. Yesus yang memposisikan diri sebagai Hamba yang penuh kuasa berhasil memuridkan dan dampak yang menjadi fokus adalah keterbukaan dari Petrus, Yakobus, Yohanes.

Dampak pertama dilihat dari sikap Petrus kepada Tuhan Yesus pada Markus 10:28-31. Petrus berani memberikan pertanyaan kepada Yesus mengenai apa yang telah dia perbuat demi Yesus. Petrus berekpekstasi untuk mendapatkan sesuatu dari Yesus. Yesus memberikan jawaban bahwa mereka yang meninggalkan segala sesuatu akan menerima ganjaran seratus kali lipat pada masa kini dan masa datang juga mendapat hidup yang kekal. ${ }^{23}$ Petrus memiliki keberanian untuk terbuka dan bertanya kepada Yesus perihal tentang apa yang telah dia lakukan untuk Yesus.

\footnotetext{
${ }^{22}$ Matthew Henry, Matthew Henry's Concise Commentary on The Bible, (Grand Rapids, MI: Christian Classics Ethereal Library, 2005)1153

${ }^{23}$ John Barton dan John Muddiman, The Oxford Bible Commentary, (United States, Oxford University Press, 2001), 889
} 
Dampak kedua dilihat dari keterbukaan Yakobus dan Yohanes dalam meminta tempat di sebelah kanan dan sebelah kiri pada Markus 10:35-45. Hal ini merupakan permintaan ambisius dari Yakobus dan Yohanes secara terbuka kepada Yesus. Sesuai ajaran Yesus, mintalah maka kamu akan diberikan maka Yakobus dan Yohanes melakukan hal tersebut. Jawaban Yesus adalah memberikan penjelasan mengenai cawan yang harus diminum dan respon Yakobus dan Yohanes pun juga mau menerima cawan tersebut. $^{24}$

Berdasarkan hal tersebut terlihat bahwa Yakobus dan Yohanes sangat terbuka pada Yesus dan berani meminta permintaan ambisius. Menariknya Yakobus dan Yohanes juga siap menerima segala risiko untuk ikut menderita dengan Kristus. Meskipun hal ini menjadi pertentangan dengan murid-murid lainnya, terlihat bahwa pemuridan Yesus, Hamba yang penuh kuasa sangat berdampak. Fokus keterbukaan Petrus, Yakobus, dan Yohanes sangat terlihat dimana mereka berani menyampaikan pendapat, keluh kesah, keinginan, dan harapannya langsung kepada Yesus. Berbeda dengan murid-murid lainnya, Petrus, Yakobus, Yohanes lebih terbuka terhadap Tuhan Yesus.

\section{Pemuridan Kontekstual (KTBK)}

Pemuridan Kontektual adalah model pemuridan yang menggunakan kontesk sebagai pertimbangan utama. Dalam hal ini baik teks Alkitab maupun pembuat

\footnotetext{
${ }^{24}$ Matthew Henry, Commentary on The Whole Bible Volume V (Matthew to John), ( Grand Rapid, MI : Christian Classics Ethereal Library, 2000), 755
}

muridnya, muridnya, materi pemuridannya, kebutuhan rohani, dan lingkungannya. Metode Pemuridan ini memakai nama KTBK atau Contextual Bible Group (CBG). Visi KTBK adalah anggota KTBK menjadi serupa dengan Yesus. Misi KTBK adalalah: pertama, mendorong ornag percaya bertubuh ke arah kedewasaan penuh dalam Kristus. Kedua, memperlengkapi orang percaya dnegan pemahaman Alkitab kontekstual. Ketiga, mengontrol orang percaya dalam ketaatan terhadap Firman Tuhan. Keempat, melipatgandakan KTBK dengan mendelegasi setiap anggota menjadi pemimpin KTBK baru. Karakteristik KTBK adalah: alkitabiah, kontekstual, terfokus, interdependensi. ${ }^{25}$

Pemimpin dalam KTBK merupakan pemimpin yang bersifat interdependensi. Hubungan pemimpin dan anggota tidak independen dengan orang lain sehingga mereka merasa tidak memerlukan orang lain, akan tetapi juga tidak dependen terhadap satu orang walaupun orang tersebut pemimpinnya atau pembina rohaninya. Anggota dan pemimpin saling tergantung satu sama lain. Mereka adalah bagian dari tubuh Kristus yang rohaninya tumbuh bersama, saling membutuhkan, saling menolong, saling mengasihi, dan saling menasehati dan saling melayani. ${ }^{26}$

Anggota pemuridan KTBK sangat efektif pada petobat-petobat baru yang mau bertumbuh ke arah Kristus ataupun orang percaya secara umum. Melalui KTBK, petobat baru akan dapat bertumbuh

\footnotetext{
${ }^{25}$ T. Haryono dan Yuliati, Pemuridan Kontekstual : Contextual Bible Group. (Surakarta, Yayasan Gamaliel, 2018), 60- 63.

${ }^{26}$ Ibid. 63
} 
lebih efektif menjadi seorang murid Kristus dan menuju dewasa serupa Yesus Kristus. KBTK memiliki kelebihan bagi anggotanya yaitu: pertama, KTBK dapat memenuhi kebutuhan anggotanya. Kedua, KTBK memberikan kesempatan anggota untuk lebih bebas dan kritis mengeluarkan ide, pendapat, berpatisipasi, berdiskusi dan berkomunikasi. ${ }^{27}$ Anggota KTBK dalam kelompok kecil yaitu 3-6 orang yang berkomitmen bertumbuh di dalam Kristus. ${ }^{28}$

Proses KTBK adalah meneladani persekutuan orang percaya yaitu: pertama, belajar Firman Allah (learning). untuk bertumbuh menuju kedewasaan penuh dan menjadi serupa dengan Kristus dibutuhkan pengajaran Firman Tuhan. Pengajaran Firman Tuhan harus disertai kerelaan dalam menaati otoritas Firman Tuhan. Dalam KTBK proses belajar dilakukan bersama dengan memahami Alkitab secara indukstif kontekstual.

Kedua, penyembahan dan doa. Penyembahan merupakan respon seseorang untuk memuji dan membesarkan Nama Tuhan. Penyembahan mengingatkan perbuatan-perbuatan Tuhan dan kasih setia-Nya. KTBK tidak dapat dipisahkan dengan unsur penyemabahan karena unsur ini membuat anggota KTBK lebih mengenal Allah. Penyembahan dapat dilakukan melalui doa, puji-pujian, kidung, pembacaan Mazmur puji-pujian, dan puisi yang berisi puji-pujian.

Ketiga, persekutuan (fellowship). Persekutuan kasih yang terjadi di antara anggota KTBK akan menyaksikan kepada orang lain bahwa mereka benar-benar

\footnotetext{
${ }^{27} \mathrm{Ibid}, 63-43$.

${ }^{28} \mathrm{Ibid}, 60$.
}

murid Kristus. Gereja mula-mula membentuk persekutuan karena mereka telah mengalami keselamatan dari Tuhan dan menyadari pentingnya persekutuan. Melalui persekutuan mereka terus bertumbuh kerohaniannya. Persekutuan dalam KTBK akan menolong semua anggota dapat saling mengasihi, saling melayani, saling membangun, saling memperhatikan, saling menasihati, mensharingkan kebutuhannya masingmasing, saling mengakui dosa-dosanya, saling menanggung beban, membesarkan hati orang lain dan saling mendoakan.

$$
\text { Keempat, Pengutusan (Missions). }
$$

KTBK terkait erat dengan pengutusan. Pengutusan adalah kesaksian anggota KTBK untuk pergi memberitakan Injil Yesus Kristus kepada orang-orang yang membutuhkannya. Melalui pengutusan ini anggota KTBK dapat mempraktikkan kasih dan kuasa Allah.

Keempat unsur di atas tidak dapat dipisahkan satu sama lain melainkan bekerja bersama-sama untuk terjadinya tujuan KTBK. ${ }^{29}$

Dampak pemuridan KTBK mahasiswa sekarang dipacu untuk kreatif dan inovati dalam menghadapi berbagai tantangan zaman, pilihan hidup, dan cara memcahkan masalah. Gaya hidup siswamahasiswa pada umumnya adalah revolusioner, dinamis, aktif, demonstratif, individualis, dan independen. Karakter yang demikian ini membutuhkan wadah pembinaan rohani yang sesuai. Kebutuhan tersebut akan terjawab dalam KTBK.

\footnotetext{
${ }^{29}$ T. Haryono dan Yuliati, Pemuridan Kontekstual : Contextual Bible Group. (Surakarta, Yayasan Gamaliel, 2018), 68- 69.
} 
Ada beberapa hal yang mendasarinya, seperti: KTBK menggunakan pendekatan pendalaman Alkitab (PA) induktif kontekstual supaya anggota berpikir kritis dan kreatif untuk memperoleh pengertian dan pesan asli dari teks Alkitab. Pendekatan PA ini memicu mahasiswa untuk terus berpikir kirtis dan terus menggali isi Alkitab. ${ }^{30}$

\section{Kecenderungan Mahasiswa pada Masa Kini}

Pendekatan mahasiswa masa kini akibat globalisasi

Globalisasi memaksa kompetisi sumber daya manusia yang sangat ketat seiringdengan arus globalisasi yang ditandai dengan era perdagangan bebas, membawa konsekuensi munculnya peluang untuk sumber mobilitas tenaga kerja yang semakin luas dan tidak terikat pada asal dan batas negara. Agarbangsa Indonesia tidak hanya menjadi penonton terhadap perebutan peluang kerja internasioanl, maka harus menyiapkan SDM yang berkualitas sehingga mampu menjadi pemain yang layak diperhitungkan karena kemampuan dan kompetensi yang dimilikinya. ${ }^{31}$ Daya saing yang tinggi ini berakibat positif dan negatif bagi mahasiswa. Salah satu dampak negatifnya adalah kecemasan atau sering dikenal khawatir, yaitu suatu pengalaman subjektif mengenai ketegangan mental yang menggelisahkan sebagai reaksi umum dan ketidakmampuan menghadapi masalah atau

\footnotetext{
${ }^{30}$ Ibid, 67

${ }^{31}$ Umar Chadiq, "Tantangan Kompetisi Global Dan Dampaknyaterhadap Tuntutan Pengembangan Kualitas Sumber Daya Manusia”, Akses: Jurnal Ekonomi dan Bisnis, Vol 1, No 2, 2006. 146.
}

adanya rasa aman. Perasaan yang tidak menyenangkan ini umumnya menimbulkan gejala-gejala fisiologis (gemetar, berkeringat, detak jantung meningkat) dan gejala-gejala psikologis (panik, tegang, bingung, tak dapat berkonsentrasi). ${ }^{32}$

Mahasiswa sangat identik dengan perasaan tersebut yaitu perasaan tidak aman, khawatir, dan kecemasan yang berlebih. Beberapa penelitian memperlihatkan kecenderungan mahasiswa yang memiliki kecemasan dan kekhawatiran akibat rasa tidak aman yaitu: Hubungan Antara Tingkat Kecemasan Dengan Tingkat Sugestibilitas Pada Mahasiswa Fakultas Kedokteran Tahun Pertama, ${ }^{33}$ Perbedaan Tingkat Kecemasan Mahasiswa dalam menghadapi Computer Based Test, ${ }^{34}$ Tingkat Kecemasan Mahasiswa dalam menyelesaikan Tugas di Fakultas Kedokteran Universitas Brawijaya, ${ }^{35}$ Dan lainya.

Berdasarkan hal tersebut oleh karena suatu perubahan yang cukup signifikan membuat Mahasiswa lebih mudah terpengaruh menjadi cemas dan ketakutan. Fokus dan daya gerak mahasiswa masa kini juga dipengaruhi oleh kecemasan dan

${ }^{32}$ Taylor, S.E, Peplau, L. A., Sears, D.O. Social phsycology. Prentice Hall: New Jersey; 1997.

${ }^{33}$ Alicia Sandjaja et al, “ Hubungan Antara Tingkat Kecemasan Dengan Tingkat Sugestibilitas pada Mahasiswa Fakultas kedokteran Tahun Pertama”, Jurnal Kedokteran Diponegoro, Vol 6, No 2, 2017, 1

${ }^{34}$ Lisa Mutiara Anissa et al, “ Tingkat Kecemasan Mahasiswa Keperawatan dalam Menghadapi Ujian Berbasis Compter Based Test", Jurnal Ilmiah Ilmu-ilmu Kesehatan, Vol 16, No 2, 2018, 1

${ }^{35}$ Heri Kristianto et al, “ Perbedaan Tingkat Kecemasan Mahasiswa dalam Menyelesaikan Tugas dengan Pembagian Kelompok Berdasarkan Metode Fridenship Group dan Random Group di Fakultas Kedoketan Universitas Brawija", Jurnal Ilmu Keperawatan, Vol 1, No 2, 2013, 1 
ketakutan akan keadaan masa depannya.

Ketakutan dan kecemasan ini yang mendukung terjadinya sikap menutup diri karena tingkat persaingan yang ketat pada masa globalisasi ini.

Peristiwa menutup diri ini juga terjadi pada Studi Mahasiswa Papua di Surabaya. Perbedaan Fisik, bahasa, kebiasaan dan budaya membuat penyesuaian diri mahasiswa Papua sukar dan cenderung untuk menutup diri. Mahasiswa Papuapun enggan dekat dengan mahasiswa lokal. ${ }^{36}$ Secara general kecenderungan itu juga mempengaruhi mahasiswa pada umumnya ketika mereka dalam posisi ketakutan dan tidak nyaman maka mereka menjadi cemas dan khawatir. Kecenderungan yang terjadi lagi adalah Mahasiswa enggan untuk bersosialisasi dan cenderung menutup diri akibat kecemasan yang dialaminya.

Penutupan diri dari mahasiswa pada masa kini akibat himpitan-himpitan rasa ketakutan akan masa depan akan mejadi masalah yang serius. Mahasiswa tidak akan bisa ditolong untuk menyelesaikan masalahnya jika mereka tetap dalam posisi menutu diri dan tidak bisa dikonseling.

Kecenderungan Mahasiwa berdasarkan data lapangan: Persekutuan Mahasiswa Kristen Surakarta.

Data lapangan diambil dengan menggunakan wawancara kepada pengurus atau aktivis PMKS yang aktif ber-KTBK. Wawancara dilakukan dengan dibatasi pada PMKS.

Pertanyaan pertama adalah apakah kecenderungan mahasiswa pada masa kini susah untuk terbuka kepada orang lain?

\footnotetext{
${ }^{36}$ Eri Wijanarko dan Muhammad Syafiq,"Studi Fenomenologi Pengalaman Penyesuaian diri Mahasiswa Papua di Surabaya", Jurnal Psikologi : Teori \& Terapan, Vol 3, No 2, 2013, 1.
}

Jawaban yang didapat dari responden adalah didominasi jawaban: benar bahwa mahasiswa memiliki kecenderungan untuk susah terbuka pada masa kini. ${ }^{37}$ Hal ini menyatakan bahwa gejala-gejala yang terjadi masa kini membuat kecendrungan mahasiswa untuk susah dalam hal keterbukaan.

Pertanyaan yang kedua, apa yang membuat anda bisa terbuka kepada seorang teman dan dapat menceritakan semua masalah? Bagian ini menjelaskan bagimana mahasiswa masa kini dapat menceritakan semua pergumulannya kepada temannya dan kualifikasi apa yang diharapkan. Jawaban yang didapat berkisar Teman yang dapat dipercaya, teman yang terbuka, teman yang dapat memberi jawaban dalam segi rohani, pendengar yang baik. ${ }^{38}$ Dari data ini didapatkan hasil bahwa mahasiswa dapat terbuka apabila temannya dapat memiliki sikap tersebut dan yang paling dominan adalah pendengar yang baik dan terbuka akan kelemahan dan kekuatannya.

Pertanyaan ketiga, apakah melalui KTBK terdapt potensi untuk mahasiswa saling terbuka dan saling mendukung? Pertanyaan ini diberikan untuk mendapatkan hasil bagaimana peran KTBK sejauh ini dalam pengaruhnya terhadap keterbuakan diri dari seorang mahasiswa. Jawaban yang didapatkan adalah bahwa KTBK memiliki potensi untuk dapat membuat mahasiswa untuk saling terbuka. ${ }^{39}$ Seluruh responden menceritakan bahwa dalam KTBK

\footnotetext{
${ }^{37}$ Disarikan dari wawancara terhadap Pengurus dan aktivis PMK Surakarta

${ }^{38}$ Ibid.

${ }^{39}$ Ibid
} 
memiliki kekuatan dalam aplikasi dan diskusi yang memicu peran aktif dari mahasiswa. Melalui sharing dan diskusi ini memicu keterbukaan untuk setiap mahasiswa dalam mencertiakan permasalahan yang sedang dihadapinya.

Pertanyaan keempat adalah bagaimana rekomendasi KBTK supaya dapat membuat anggotanya saling percaya dan saling terbuka? Pertanyaan ini diharapkan digunakan untuk mendapatkan data-data yang dapat melengkapi potensi KTBK dalam membuat mahasiswa saling terbuka dan dapat dikonseling. Jawaban yang di dapat adalah pemimpin harus lebih mendengarkan, pemimpin mengawali dengan keterbukaan, pemimpin yang menjadi sahabat, dan kegiatan fellowship bersama. ${ }^{40}$ Rekomendasi di atas didapat dari data wawancara bahwa berdasarkan responden cara-cara diatas akan dapat meningkatkan keterbukaan dari anggota KTBK.

\section{Analisis}

Persamaan dan perbedaan anggota Pemuridan Yesus dan anggota Pemuridan KTBK terhadap mahasiswa pada masa kini

Berdasarkan kajian pustaka dan lapangan di atas dapat didapatkan hasil persamaan antara Petrus, Yakobus, dan Yohanes dengan konteks mahasiswa pada masa kini. Pada zaman Yesus, Israel dikuasai oleh Romawi, keadaan yang secara ekonomi tidak bebas dan terhimpit. Kaum rohaniawan atau Sanhedrin pun seolah-olah condong ke pemerintahan

${ }^{40} \mathrm{Ibid}$
Romawi dan tidak ke pada rakyat. Pada masa globalisasi, persaingan yang membuat menghimpit sehingga setiap orang mencari financial freedom. Dua keadaan tersebut memaksa setiap orang untuk bersikap egois dan sulit terbuka dengan orang lain. Keadaan terhimpit secara ekonomi menjadi modus untuk susah terbuka dengan siapapun. Meskipun secara umur konteks Petrus, Yakobus, dan Yohanes dengan mahasiswa sekarang memiliki keberbedaan pada umur akan tetapi dampak dari masalah yang dihadapi sama.

Persamaan dan perbedaan Pemimpin Pemuridan Yesus dan anggota Pemuridan KTBK terhadap mahasiswa pada masa kini

Persamaan Yesus dan pemimpin KTBK pada masa kini adalah bahwa keduanya memiliki kesadaran untuk digerakan oleh Visi. Visi menjadi landasan utama bagi pelaksaaan pemuridan untuk digerakan. Pemimpin yang mencari dan mengerjakan panggilan Ilahi untuk memuridkan semua orang untuk menjadi serupa dengan Yesus. Tanpa Visi setiap pemimpin tidak akan kuat dalam menghadapi tantangan.

Persamaan kedua adalah bahwa pemimpin adalah hamba. Yesus sebagai pemimpin di ekspos dalam kitab Markus sebagai Hamba yang penuh kuasa. Yesus melayani murid-muridnya terkhusus pada Petrus, Yakobus, dan Yohanes dengan pengajaran dan pengalaman-pengalaman bersama dengan-Nya. Pemimpin KTBK juga adalah hamba, melalui relasi interdependensi saling menguatkan dan belajar bersama terhadap kebenaran Firman Tuhan. 
Persamaan ketiga adalah bahwa Yesus mendorong keterbukaan kepada murid-muridnya, selalu mendengar, dan mengonseling setiap masalah yang menjadi beban para murid-Nya. Yesus hamba yang penuh memberikan dirinya sepenuhnya dalam pemuridan yang dikerjakan-Nya. Pemimpin KTBK diharapkan juga memiliki fellowship yang kuat dengan anggotanya dan bisa menjadi problem solver ketika ada pergumulan yang dihadapi dengan mengacu kepada kebenaran Firman Tuhan.

Perbedaanya adalah bahwa pemimpin KTBK goal utamanya adalah meneladan Yesus seorang hamba yang penuh kuasa. Yesus menjadi goal bagi pemimpin dan anggota KTBK masingmasing. Pemimpin KTBK dan anggota harus siap untuk diproses bersama-sama menjadi serupa Yesus.

Analisis model Pemuridan Yesus dengan pemuridan KTBK bagi konteks Mahasiswa pada masa kini

\begin{tabular}{|c|c|c|}
\hline $\begin{array}{c}\text { Pemuridan } \\
\text { Yesus }\end{array}$ & $\begin{array}{c}\text { Pemuridan } \\
\text { KTBK }\end{array}$ & Sintesis \\
\hline $\begin{array}{l}\text { Pemimpin } \\
\text { dapat } \\
\text { membuat } \\
\text { mukjizat, } \\
\text { Pemimimpin } \\
\text { dapat } \\
\text { mengajar } \\
\text { Firman, } \\
\text { penuh hikmat } \\
\text { dan terbuka }\end{array}$ & $\begin{array}{l}\text { Pemimpin } \\
\text { Fasiltator } \\
\text { dalam } \\
\text { mempelajari } \\
\text { Firman }\end{array}$ & $\begin{array}{l}\text { Pemimpin } \\
\text { KTBK yang } \\
\text { dapat menjadi } \\
\text { fasilitator } \\
\text { dalam } \\
\text { mempelajari } \\
\text { Firman Tuhan, } \\
\text { penuh hikmat, } \\
\text { terbuka dan, } \\
\text { meyakinkan } \\
\text { kepada anggota } \\
\text { bahwa ada } \\
\text { mukjizat dan } \\
\text { pekerjaan } \\
\text { Tuhan yang } \\
\text { luar biasa }\end{array}$ \\
\hline Anggota & Anggota ada & Perlu \\
\hline
\end{tabular}

\begin{tabular}{|c|c|c|}
\hline terpanggil & $\begin{array}{l}\text { yang terpanggil } \\
\text { ada yang tidak }\end{array}$ & $\begin{array}{l}\text { memotivasi } \\
\text { untuk anggota } \\
\text { ikut dalam } \\
\text { panggilan } \\
\text { pemuridan } \\
\text { kontekstual } \\
\text { dalam rangka } \\
\text { melaksanakan } \\
\text { Visi Tuhan }\end{array}$ \\
\hline $\begin{array}{l}\text { Pemimpin } \\
\text { mengajar dan } \\
\text { berintegritas } \\
\text { melakukannn } \\
\text { ya, Pemimpin } \\
\text { menjamin } \\
\text { setiap } \\
\text { kebenaran } \\
\text { yang } \\
\text { diajarkan }\end{array}$ & $\begin{array}{l}\text { Proses } \\
\text { Learning, Doa } \\
\text { Penyembahan, } \\
\text { Feslowship, } \\
\text { Missions }\end{array}$ & $\begin{array}{l}\text { Proses } \\
\text { Learning, Doa } \\
\text { Penyembahan, } \\
\text { Fellowship, } \\
\text { Mission, harus } \\
\text { didasari dari } \\
\text { integritas dan } \\
\text { keyakinan } \\
\text { bahwa hal } \\
\text { tersebut ada } \\
\text { kuasa. }\end{array}$ \\
\hline
\end{tabular}

Andil Model Pemuridan Kontekstual Yesus kepada Petrus, Yakobus, dan Yohanes bagi keterbukaan Konseling bagi Mahasiswa pada masa kini.

Berdasarkan analisis di atas didapatkan andil Model Pemuridan Kontekstual Yesus Kepada Petrus, Yakobus dan Yohanes bagi keterbukaan konseling pada masa kini. Hal tersebut di deskripsikan dalam tiga hal yaitu: peran pemimpin, peran anggota, dan proses pemuridan dalam kaitanya dengan keterbukaan konseling bagi mahasiswa pada masa kini.

\section{Pertama, Andil Pemimpin Pemuridan}

\section{Kontekstual dalam Keterbukaan}

\section{Konseling Bagi Mahasiswa Pada Masa}

Kini.

Pemimpin Pemuridan Kontekstual (KTBK) harus dapat menjadi fasilitator dalam mempelajari Firman Tuhan, penuh hikmat, terbuka, dan meyakinkan kepada 
anggota bahwa ada mukjizat dan pekerjaan Tuhan yang luar biasa. Pemimpin KTBK meneladani Yesus dalam menjadi hamba. Pemimpin harus terbuka namun juga tetapi menjaga wibawa dalam setiap pelayanan yang dilakukan. Menjadi pemimpin tidak perlu takut untuk mengakui kelemanan namun memberikan teladan bagaimana dapat mengatasi kelemahan tersebut.

Pemimpin mengarahkan untuk memandang setiap masalah atau pergumulan ke arah Kristus dan menguatkan fellowship dari hal-hal kecil hingga hal-hal yang urgent dan mendesak.

Pemimpin yang mengedepankan keyakinan bahwa dalam pembelajaran Firman dan dalam Yesus ada jaminan atas penyelesaian masalah akan membuat anggota terbuka dan menyadari pertolongan ada dalam Yesus. Proses konseling dapat dilakukan apabila anggota KTBK dapat menyadari dan terbuka masalahnya dan dengan kekuatannya bersama dengan Yesus dapat mengatasi permasalahan tersebut.

Pemimpin mendorong penyelesaian masalah, baik masalah pergumulan pribadi atau pertumbuhan rohani dengan mengarahkan kepada Tuhan Yesus. Pemimpin juga harus menyaksikan kebaikan Tuhan Yesus dalam hidupnya sehingga setiap anggota KTBK menyakini seperti yang dilakukan Yesus ketika menyembuhkan anak Yairus.

\section{Kedua, Andil Anggota Pemuridan Kontekstual dalam Keterbukaan Konseling Bagi Mahasiswa Pada Masa Kini.}

Kebanyakan anggota KTBK belum menyadari dan belum termotivasi untuk menjadi murid. Hal ini berbeda dengan Petrus, Yakobus, dan Yohanes ketika pertama kali dipanggil menjadi Muris Yesus. Dalam hal ini anggota KTBK harus disadarkan pentingnya bertumbuh melalui KTBK. Anggota KTBK harus merasakan nyaman dan mengerti bahwa tempat ini adalah tempat yang tepat untuk bertumbuh. Yesus senantiasan menjamin dan memenuhi kebutuhan anggotanya, maka anggota KTBK juga harus dapat merasakan providensia Yesus melalui proses KTBK.

Anggota KTBK yang menyadari panggilannya dalam proses KTBK akan menyadari pentingnya bertumbuh ke arah Yesus. Melalui Hal ini diharapkan anggota KTBK dapat terbuka ketika mereka dari hati memiliki keinginan untuk mengikut Yesus seperti yang dilakukan oleh Petrus, Yakobus, dan Yohanes. Proses konseling akan mudah dilakukan jika anggota KTBK meyadari pentingnya bertumbuh melalui KTBK.

\section{Ketiga Andil Proses Pemuridan Kontekstual dalam Keterbukaan Konseling Bagi Mahasiswa Pada Masa Kini.}

Proses Learning, Doa Penyembahan, Fellowship, Mission, harus didasari dari integritas dan keyakinan bahwa hal tersebut ada kuasa. Setiap proses yang diyakini dalam KTBK harus memiliki keyakinan bahwa ada kuasa baik kuasa untuk menambah kapasitas kognitif, rohani dan mental. Apabila proses KTBK hanya dilakukan dan dianggap sebagai rutinitas untuk mempelajari Firman Tuhan tanpa menyadari ada kuasa Roh Kudus yang di curahkan maka proses Pemuridan akan menjadi sia-sia. Proses pemuridan harus disadari akan adanya kuasan dari permuridan itu. 
Mukjizat menyembuhkan anak Yairusdan kuasa transfigurasi Yesus dipermuliakan yang ditunjukan Yesus terkhusus kepada Yakobus, Yohanes dan Petrus mendorong keterbukaan mereka dan membuat mereka berani menyampaikan isi hatinya kepada Yesus. Hal ini juga akan mendorong anggota KTBK dalam terbuka ketika mereka menyadari bahwa dalam proses KTBK ada Kuasa ilahi.

\section{Kesimpulan dan Saran}

Berdasarkan hal di atas dapat disimpulkan bahwa melalui pemuridan Kontesktual yang didasari dari pemuridan Yesus kepad Petrus, Yakobus, dan Yohanes dapat memberikan andil dalam keterbukaan konseling bagi mahasiswa pada masa kini. Keterbukaan ini nanti yang nantinya akan membuat mahasiswa dapat dikonseling dan menyadari masalahnya sesungguhnya dan ditolong bahwa di dalam Yesus ada penyelesaian masalah tersebut.

Saran dari penelitian ini adalah perlu dilakukan penelitian lanjutan secara kuantitatif berapa presentase andil ktbk ini dalam proses keterbukaan mahasiswa melalui pemuridan kontekstual (KTBK) yang didasari dari Pemuridan Yesus kepada Petrus, Yakobus, dan Yohanes.

\section{Daftar Pustaka}

Anissa, Lisa Mutiara et al. " Tingkat Kecemasan Mahasiswa Keperawatan dalam Menghadapi Ujian Berbasis Compter Based Test”, Jurnal Ilmiah Ilmu-ilmu Kesehatan, Vol 16, No 2, 2018.

Azmy, Ahmad. "Pengembangan Kompetensi Sumber Daya Manusia Untuk Mencapai Career Ready Professional Di Universitas
Tanri Abeng", Jurnal Binus Bussines

Review, Vol 6, No 2, 2015.

Barton, John dan John Muddiman,. The Oxford Bible Commentary, United States, Oxford University Press, 2001.

Bruce, A. B. The Training of the tweleve, Gran Rapids: Kregel Publication, 1984.

Chadiq, Umar."Tantangan Kompetisi Global Dan Dampaknyaterhadap Tuntutan Pengembangan Kualitas Sumber Daya Manusia”, Akses: Jurnal Ekonomi dan Bisnis, Vol 1, No 2, 2006.

Coleman, Robert. Rencana Agung Penginjilan. Bandung: Kalam Hidup, 1964.

Gamayanti, Witrin et al. "Self Disclosure dan Tingkat Stres pada Mahasiswa yang sedang Mengerjakan Skripsi”, Psymphatic: Jurnal Ilmiah Psikologi. Vol 5, No 1, 2018. 115.

Haryono, T. dan Yuliati. Pemuridan Kontekstual : Contextual Bible Group. Surakarta, Yayasan Gamaliel, 2018.

Henry, Matthew. Matthew Henry's Concise Commentary on The Bible, Grand Rapids, MI: Christian Classics Ethereal Library, 2005.

Henry, Matthew. Commentary on The Whole Bible Volume V (Matthew to John), Grand Rapid, MI : Christian Classics Ethereal Library, 2000.

Hull, Bill. Jesus Christ, Disciplemarker, Surabaya: Literatur perkantas, 2015.

Jamieson, Robert et al. Commentary Critical and Explanatory on the Whole Bible, ( Grand Rapid, MI : Christian Classics Ethereal Library,2009) 2215

Kristianto, Heri et al. “ Perbedaan Tingkat Kecemasan Mahasiswa dalam Menyelesaikan Tugas dengan Pembagian Kelompok Berdasarkan Metode Fridenship Group dan Random Group di Fakultas Kedoketan Universitas Brawija”, Jurnal Ilmu Keperawatan, Vol 1, No 2, 2013.

Nastiti, Dwi dan Nur Habibah . "Studi Eksplorasi tentang Pentingnya Layanan Bimbingan Konseling Bagi Mahasiswa di 
UMISIDA", Psikologia : Jurnal

Psikologi, Vol 1, No 1, 2016.

S.E,Taylor, Peplau, L. A., Sears, D.O. Social phsycology. Prentice Hall: New Jersey; 1997.

Sandjaja, Alicia et al." Hubungan Antara Tingkat Kecemasan Dengan Tingkat Sugestibilitas pada Mahasiswa Fakultas kedokteran Tahun Pertama”, Jurnal Kedokteran Diponegoro, Vol 6, No 2, 2017.

Rohmah, Faridah Ainur. "Pengaruh Diskusi Kelompok Untuk Menurunkan Stres Pada Mahasiswa Yang Sedang Skripsi", Humanitas: Indonesian Psychological Journal, Vol 3, No 1, 2006.

Ruhana, Ika . "Pengembangan Kualitas Sumber Daya Manusia VS Daya Saing Global", Jurnal Profit, Vol 6, No 1, 2012.

Tamjuddin. "Kapasistas UMKM Menghadapi Pasar Global”, Semonas Fekon : optimsme ekonomi Indonesia 2013, antara peluang dan tantangan. 2013.

Wijanarko, Eri dan Muhammad Syafiq. "Studi Fenomenologi Pengalaman Penyesuaian diri Mahasiswa Papua di Surabaya", Jurnal Psikologi : Teori \& Terapan, Vol 3, No 2, 2013,

Wilkinson, Bruce dan Kenneth Boa,Talk Thru bible, Malang: Gandum Mas, 2017. 